BATAller, Alexandre; Héctor H. GASsó ; Antonio MARTín (eds.): Festa popular, territori i educació. València: Publicacions de la Universitat de València, 20I7, I90 p.

\title{
Festa popular, territori i educació
}

Isabel MARCILLAS PIQUER

Universitat d'Alacant

Festa popular, territori i educació és un volum col-lectiu, publicat per la Universitat de València, a cura d'Alexandre Bataller, Héctor H. Gassó i Antonio Martín, membres del Departament de Didàctica de la Llengua i la Literatura de l'esmentada universitat. La temàtica del llibre queda ben descrita i resumida a partir del mateix títol que, encertadament, indica els eixos clau al voltant dels quals giraran els setze articles que s'hi presenten. Sens dubte, l'educació és la pedra angular de la nostra societat $i$, en aquest sentit, unir-la al concepte de territori ens permet apropar-nos als models educatius proposats, a principis del segle xx, pels corrents de renovació pedagògica que, encara ara, se'ns mostren amb una forta vigència. Educar tenint en compte els principis que arrelen els infants al propi territori és, gairebé, sinònim d'èxit educatiu, atenent el factor vivencial que els vincles afectius amb la pròpia terra i la pròpia quotidianitat suposen. Si, a tot això, hi sumem el goig dels menuts per les manifestacions col-lectives d'àmbit festiu, trobem a l'abast un esquema potent de construcció didàctica i pedagògica de caire identitari. Així doncs, és en aquest sentit que el llibre que presentem s'erigeix en una eina valuosa que cal tenir en compte en el marc docent.

Com a dades rellevants, cal comentar que els estudis que s'hi inclouen sorgiren a l'empara del VI Curs de Cultura Popular i II Jornades Literatura, Territori i Educació, que es van celebrar a Ontinyent i Bocairent a l'abril de l'any 20I5, com a resultat dels esforços conjunts de la Xarxa d'Innovació Geografies Literàries i del Grup d'Estudis Etnopoètics, aliança que demostra la vigència dels estudis relacionats amb aquesta branca del coneixement. Altrament, resulta destacable el fet que el llibre està elaborat a partir de quatre llengües diferents: català, francès, anglès i castellà. Tot i que la llengua majoritària siga el català, la barreja idiomàtica és una mostra més de la importància que adquireix la interculturalitat no solament en l'àmbit investigador, sinó també a les aules, ja siga com a forma d'expressió de la pròpia cultura, ja siga com a forma de conviure i definir l'alteritat cultural.

El volum es divideix en quatre seccions que porten com a títol «La dimensió literària», «L'expressió carnavalesca», «El component ciutadà i identitari» i «Projectes i experiències educatives». En referència a la primera, hi donen cos els articles de Joan Borja, «Festa i poètica popular»; Tatiana Jordà, «Els elements literaris i teatrals de les festes populars valencianes com a recursos didàctics»; Salvador Palomar, «Teatre popular a l'entorn de la festa de Sant Antoni», i Llorenç Soldevila, que presenta un estudi sota l'epígraf «La Patum, la Muixiganga i els Castellers: centres de la festa a Endrets.Cat». Tots quatre treballs tenen com a punt en comú la defensa de la paraula com a eix central de la festa; paraula que, tant en la seua manifestació oral com escrita, forma part d'un corpus literari que hauria d'estar present en les nostres escoles. Des dels versos que componen el Misteri d'Elx, el Cant de la Sibil.la o les més de 30.000 composicions documentades que formen els gojos fins a la Patum, la Muixeranga o els Castells, la paraula revestida dels atri- 
buts de la poètica popular pren els carrers i dóna forma a manifestacions diverses de caire religiós o profà. Així, la literatura popular s'ensenyoreix de pobles, viles i ciutats i no es pot ignorar a les aules, ateses les innombrables possibilitats didàctiques que ens ofereix.

La secció dedicada a l'expressió carnavalesca inclou els articles de Jaume Guiscafrè, «La simbombada: una performance carnavalesca del llevant mallorquí»; Ángel Narro, «Le carnaval de Guadeloupe dans la littérature antillaise. Une approche didactique», i Caterina Valriu, el treball de la qual porta com a títol «L'antiga festa de Carnaval o Darrers Dies a Mallorca, una aproximació». Tal com suggereix el títol del seu estudi, Guiscafrè defensa la simbombada com a performance complexa que transmet coneixement social, memòria i sentit d'identitat i que, per tant, es contraposa a les mostres de Carnaval estandarditzades, que han perdut els seus vincles amb el costumari tradicional. Per la seua banda, Ángel Narro aposta per les festes carnavalesques a l'illa de Guadalupe com a possible ferramenta que permeta treballar la llengua francesa i d'altres facetes de la cultura francòfona, en els cursos de Français Langue Étrangère, però també en l'ensenyament secundari i dins del marc dels nous programes multilingües. En aquest sentit, Narro argumenta la necessitat de deixar de banda conceptes relacionats amb l'exotisme en referència a algunes regions i pobles que pertanyen a la francofonia. L'objectiu últim és aconseguir la formació d'individus respectuosos i amb un posicionament humanista davant per davant de cultures diferents a la pròpia. Tanca aquesta secció l'estudi de Caterina Valriu, que fa un repàs de les diverses manifestacions del carnaval mallorquí de finals del segle xIx i primeres dècades del xx, tot posant l'accent en els quatre pilars fonamentals que formen la tradició carnavalesca: «el joc de la inversió, la sàtira i la crítica vers la realitat quotidiana, la permissivitat i llicència en temes sexuals i el menjar i veure sense restriccions» (p. 89).

El component ciutadà i identitari, títol de la tercera secció d'aquest volum, dóna cabuda als treballs d'Antonio Martín, «La alteridad y el descubrimiento de lo propio. Propuesta de una lectura dialògica de los Diarios de George Ticknor»; David Parra i Josep Ramon Segarra, «Festes i tradicions historicoculturals en l'escola: potencialitats i reptes per a una educació ciutadana»; Emili Samper, «La Baixada de l'Àliga de Tarragona: l'èxit d'un acte festiu espontani», i Tomàs Vibot, «La Festa de l'Estendard. Diada Nacional de Mallorca». Així, Antonio Martín es refereix a la mirada del foraster contraposada a la de l'autòcton, com a punt de partida per a la reflexió sobre la difusió de determinats estereotips i el conreu d'algunes manifestacions festives, com ara la dels bous o «Fiesta Nacional», que s'aprofiten per dibuixar el prototipus d'espanyol. A més, a banda de los Diarios de Ticknor, Martín se serveix d'altres textos literaris per plantejar algunes propostes didàctiques. A continuació, Parra i Segarra analitzen l'educació per a la ciutadania a partir del tractament escolar de la festa del Nou d'Octubre, una festa amb inqüestionables implicacions històriques i identitàries que sovint es banalitza. Segons les fonts emprades pels investigadors, la introducció d'activitats de caràcter lúdic i festiu sol caracteritzar aquestes jornades en els centres escolars, en els quals es tendeix a obviar qualsevol implicació sociopolítica, de tal forma que s'empobreix l'educació cívica dels infants. Tot seguit, Emili Samper aborda el tema de la Baixada de l'Àliga, una cercavila nocturna que té lloc a Tarragona la nit del 2I de setembre: es tracta d'un acte festiu que va sorgir l'any I986 per espontaneïtat popular i que 
s'ha anat consolidant i institucionalitzant amb el pas dels anys. A l'últim, clou la secció l'article de Vibot, adreçat a l'estudi de la Festa de l'Estendard de Mallorca, en commemoració de l'entrada a Madina Mayurqa, el 3I de desembre de I229, de les tropes del rei Jaume I. L'autor se centra en el fet que, tot i que la festa està molt desvirtuada en l'actualitat, des de principis dels anys huitanta molts mallorquins la consideren com un esdeveniment reivindicatiu dels drets històrics, culturals i identitaris. En aquest sentit, Vibot hi planteja la necessitat de la projecció didàctica d'aquesta celebració, aglutinadora de diferents elements que permeten el treball transversal dels eixos curriculars.

Pel que fa a la secció dedicada als projectes i les experiències educatives, se n'hi presenten cinc de diferents: «Festa a l'escola: projectes i experiències didàctiques per a l'àrea de llengua i literatura», de la mà d'Alexandre Bataller; «La implicació de l'alumnat en projectes de literatura i territori», presentat per Glòria Bordons; «From Bonfire Night to Hawaiian Lei day: festivities as a way to develop the intercultural competence in the EFL classroom in pre-primary and primary levels», les autores del qual són Cynthia Couriel, Amparo Fernández i Leonor Medina; Anna Gispert defensa la proposta que porta per títol «De la paraula a la Festa. Una interpretació de Santa Tecla a Tarragona», i, per finalitzar, Margarida Prats ens aproxima al Nadal barceloní a través d' «Un projecte per treballar les festes de Nadal a Educació Infantil basat en la il.luminació nadalenca de Barcelona». En general, tots aquests estudis incideixen en la idea fonamental que expressa Bataller en la seua investigació: «Cal contemplar la festa dins de l'escola tant des de la perspectiva didàctica com des de la perspectiva de les relacions escolars, de la vivència comunitària i de les relacions amb el medi humà» (p. I45). Per aquest motiu, s'hi reivindica la necessitat d'incloure la temàtica festiva popular i tradicional, més pròxima als infants i joves, en els currículums escolars de les diferents etapes.

A tall de cloenda, cal remarcar la pertinença de l'edició del volum Festa popular, territori i educació en uns moments en què el mateix món global en el qual ens trobem immersos ens convida a preguntar-nos cada vegada amb més assiduïtat d'on venim i qui som. Les reflexions, les propostes i les aplicacions didàctiques que planteja el llibre ens ajudaran a cercar-ne les respostes i a comprovar que, sens dubte, l'experimentació i el gaudi a través de les nostres festes populars refermaran la identitat del nostre alumnat, alhora que li ensenyaran a mostrar-se més integrador en l'àmbit escolar ja multicultural al qual pertany. 